\title{
Coal Kuznets Curve in INDIA
}

\author{
Emrah Beşe \\ Texas A\&M University - Corpus Christi
}

\author{
H. Swint Friday \\ Texas A\&M University - RELLIS
}

In this study, the relationship between economic growth and emissions from coal consumption per capita is analyzed in India for the period 1960 to 2019. Although coal constitutes 70\% of energy needs of India currently, India has been investing significantly in renewable energy to make clean energy meet half of its needs in the near future. This study does not confirm relationship between emissions and economic growth in the long-run in per capita terms. Total consumption terms may be analyzed in the future studies since this study does not analyze the total consumption terms because the model does not satisfy the stability requirements. For per capita analysis, the result is inverted $N$ relationship between emissions and economic growth. Although the coefficients are insignificant, inverted $N$ relationship between economic growth and emissions shows that there may be unsustainability in economic activities due to economic policies in India. Future studies may analyze different periods with different methodologies in India for the relationship between coal consumption and economic growth.

Keywords: India, coal Kuznets curve, environmental Kuznets curve, economic growth

\section{INTRODUCTION}

India's economy in terms of GDP rank is $7^{\text {th }}$ in the world. India is also ranked as $2^{\text {nd }}$ for coal consumption and production in the world and ranked as $3^{\text {rd }}$ for greenhouse gas emissions. India also has a huge population which is also expected to surpass China within next decade as becoming the world's most populous country. This study aims to analyze the relationship between economic growth and emissions from coal consumption as per capita in India for the period 1960 to 2019. India's GDP per capita and coal consumption emissions per capita are on the rise since 1960 till today and it is important to study the relationship between them since economic growth is one of the top issues in India (see Figure 1 and Figure 2). As mentioned above, India has a role in the world in both economic and environmental terms. Although, greenhouse gas emissions-economic growth nexus is studied in the literature, this is the first study in the literature that examines the effect of economic growth on emissions from coal consumption in India. The main question of this study is that how economic growth effects coal consumption emissions per capita in the long-run in cubic terms. For future studies, total emissions from coal consumption can also be taken into consideration. This study did not take into consideration total emissions from coal consumption since the stability of the model cannot be satisfied for the period 1960 to 2019. Coal is still the main source for energy in India by constituting $70 \%$ of all energy needs. This started to change in India, by Indian 
government subsidizing and supporting renewable energy industry. Following introduction section rest of this study is as follows literature review, materials and methods, results, discussion, and conclusion.

\section{FIGURE 1 \\ GDP OF INDIA}

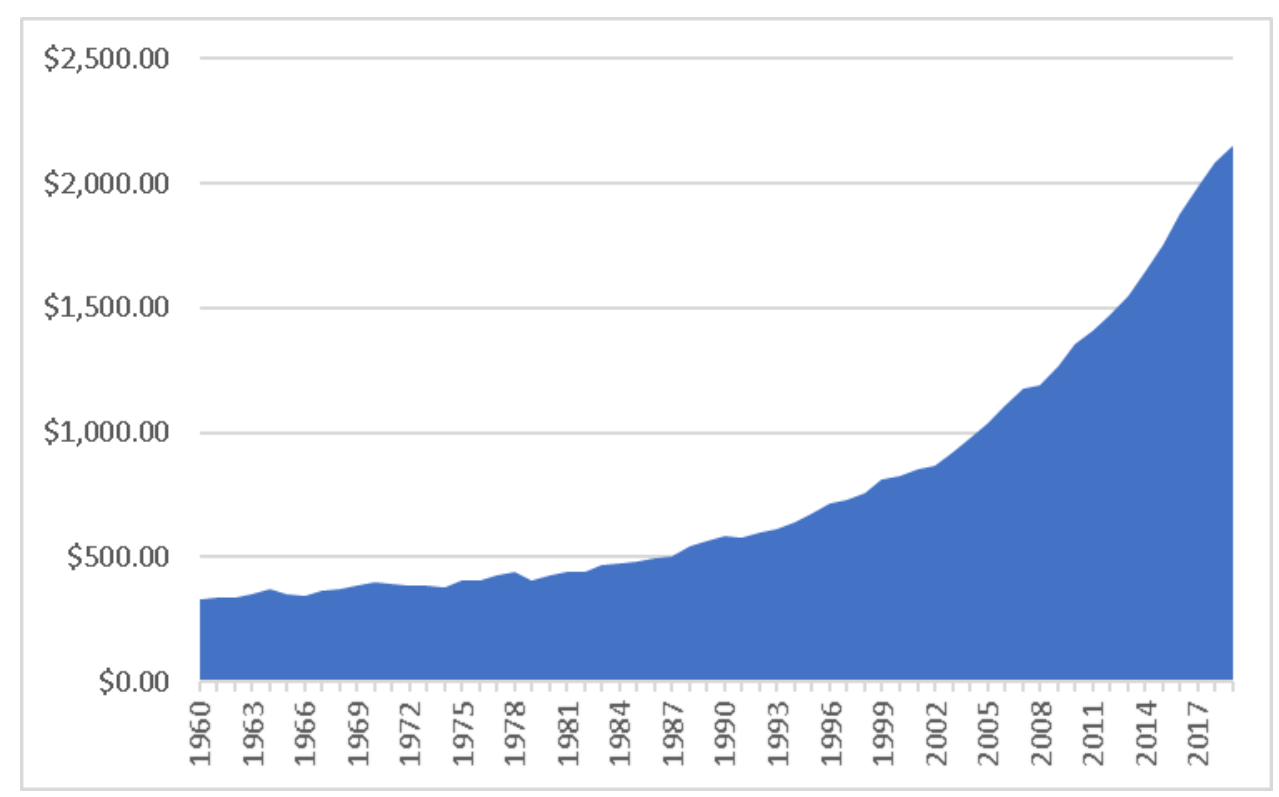

FIGURE 2

EMISSIONS FROM COAL CONSUMPTION PER CAPITA of INDIA

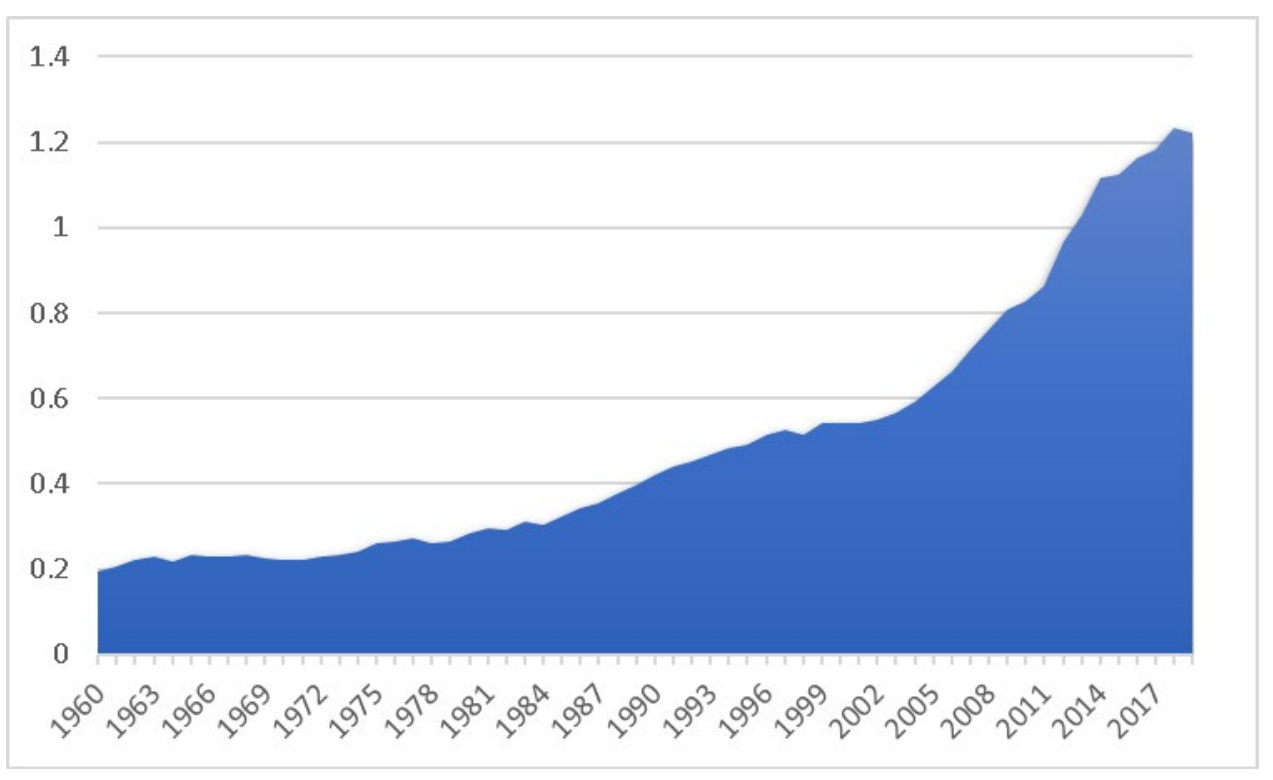

\section{LITERATURE REVIEW}

This study follows the study of Hao, Liu, Weng, and Gao (2016) which is the first in the literature to examine the relationship between emissions from coal consumption and economic growth. Hao, Liu, Weng, and Gao (2016) named this relationship as coal Kuznets curve and this study continues to name this 
relationship as coal Kuznets curve as well. For further studies that examine coal Kuznet curve, Magazzino, Bekun, Etokakpan, and Uzuner (2020) also confirmed coal Kuznets curve in South Africa for the period 1965 to 2017.

For the EKC hypothesis and economic growth related studies, Abul et al. (2019) investigated the relationship between energy use, economic growth and emissions for Gulf Cooperation Council countries for the period 1980 to 2014. Abul et al. found that economic growth leads to increase in energy use. Satrovic et al. (2020) analyzed the relationship between emissions, energy use and economic growth for Turkey and Kuwait for the period 1971 to 2014. Satrovic et al. confirmed bi-directional causal relationships between energy use, emissions and economic growth for Turkey and Kuwait. Muslija et al. (2017) analyzed the impact of tourism related earning on economic growth for a panel of 113 countries for the period 1995 to 2015. Muslija et al. found that tourism related earnings have positive impact on economic growth for panel countries in the study. Satrovic and Muslija (2018) analyzed the variables that have impact on life insurance through economic and demographic variables. Satrovic and Muslija concluded that economic and demographic variables have positive impact on life insurance, and impact of economic variables are higher than demographic variables for a panel of 150 countries for the period 2005 to 2010. Ahmad et al. (2021) examined the EKC hypothesis for a panel of 11 countries for the period 1992 and 2014. Ahmad et al. found that panel countries have inverted $U$ relationship between economic growth and emissions. Ahmad et al. discovered the EKC hypothesis for Turkey, Thailand, Russia, Malaysia, India, China and Brazil for country specific analysis. Ahmad et al. did not find evidence for the EKC hypothesis for South Africa, Indonesia, Philippines and Mexico. Verbic et al. (2021) confirmed the EKC hypothesis for a panel of Southeastern Europe countries with urbanization, emissions, economic growth and energy use for the period 1997 to 2014. Verbic et al. also confirmed that causality running from economic growth to emissions.

For India and the EKC hypothesis related studies, Saxena and Shanker (2017) confirmed negative relationship between external debt and economic development for India for the period 1991 to 2016. Although a negative relationship is found, up to a certain level of external debt, external debt positively affects economic development. Nath (2020) examined the relationship between external debt, export and economic development in India for the period 1970 to 2018. Nath confirmed that the effect of external debt on economic growth is positive in India. Irfan, Rao, Akbar, and Younis (2020) analyzed the moderating effect of capital formation for external debt an stock market performance for Pakistan, Sri Lanka, Bangladesh and India for the period 1992 to 2017. Irfan, Rao, Akbar, and Younis confirmed that capital formation has a positive effect for external debt and stock performance and external debt has negative effect on economic development. Chisti and Shabir (2019) analyzed the effect of external debt on economic development, government spending, revenue, inflation and exports in India for the period 2007 to 2017 on quarterly data. Chisti and Shabir confirmed that there is no significant relationship between external debt and economic development, external debt and export, external debt and revenue, and external debt and government spending. They found that external debt causes increase in inflation. Pahwa (2018) examined the relationships between external debt, internal debt, population, investment and trade openness for India for the period 1980 to 2014. Pahwa confirmed that external debt and internal debt affect economic growth significantly and negatively. Joy and Panda (2019) analyzed the relationship between external debt, external debt servicing, gross domestic capital formation, gross domestic savings, developmental expenditure, nondevelopmental expenditure, export, inflation and foreign direct investment for India. Joy and Panda confirmed the long run relationship between the variables. Joy and Panda confirmed that external debt postively affected inflation but negatively affected non-developmental expenditure. Sinha and Bhatt (2017) analyzed the relationship between nitrogen dioxide emissions (NO2), CE and economic growth for India. Sinha and Bhatt examined CE for 1960 to 2011 and NO2 for 1970 to 2012. Sinha and Bhatt confirmed Nshaped relatinship between emissions and economic growth for NO2 and CE. Sultan, Alkhateeb, and Adow (2021) confirmed the EKC hypothesis in India for the period 1978 to 2014. Murthy and Gambhir (2018) confirmed N-shaped relationship between CE and economic development in India for the period 1991 to 2014. Khan et al. (2020) confirmed the EKC hypothesis for panel countries of China, India and Pakistan for the period 1970 to 2016. Khan et al. confirmed U-shaped relationship between ecological footprint and 
economic development for India and China, and the EKC hypothesis for Pakistan for the period 1970 to 2016. Alam and Adil (2019) did not confirm the EKC hypothesis in India for the period 1971 to 2016.

For further studies related with the EKC hypothesis, Beşe and Kalayci (2019a) examined the EKC hypothesis for Spain, Denmark and UK for the period 1960 to 2014. Beşe and Kalayci did not confirm the EKC hypothesis for the related countries. Beşe, Friday, and Ozden (2021) analyzed the effect of external debt on emissions for China for the period 1978 to 2014. Beşe, Friday, and Ozden confirmed the positive and significant effect of external debt on emissions for China. The study did not confirm the EKC hypothesis in China. Özden and Beşe (2021) analyzed the EKC hypothesis in Australia for the period 1960 to 2014. Özden and Beşe found that there was no EKC hypothesis in Australia and there was no causal relationships between emissions and economic growth in Australia. Beşe, Friday, and Spencer (2021) did not confirm the EKC hypothesis in Australia, Finland, Estonia, South Africa and Sweden. Beșe, Friday, and Özden (2020) confirmed Coal Kuznets Curve in China for the period 1980 to 2014, and confirmed Coal Kuznets Curve in Australia for the period 1980 to 2016 in Australia. Bese and Friday (2021) confirmed that Kyoto Protocol did not have significant impact on emissions for panel countries of developed and developing countries. Beşe and Kalayci (2019b) did not confirm the EKC hypothesis in Turkey, Egypt and Kenya for the period 1971 and 2014. Balli, Nugent, Coskun, and Sigeze (2020) analyzed the EKC hypothesis in Turkey by using different methodologies and suggested that Turkey should invest significantly in renewable energy resources. Tirgil, Acar, and Ozgur (2021) analyzed the EKC hypothesis in Turkey and concluded that there exiss $\mathrm{N}$ shaped relationship between economic growth and sulfur dioxide in Turkey. Azam (2019) analyzed the effect of physical capital, financial development, human capital, energy and environmental ollution on economic growth for China, South Africa, India and Brazil. Azam concluded that financial development, energy use, human capital and physical capital affected economic growth for China, South Africa, India and Brazil. Caglar (2020) analyzed the relationship between foreign direct investment, economic growth, non-renewable energy consumption, renewable energy consumption and emissions for Norway, Portugal, Sweden, India, Italy, Morocco, Denmark, Finland and France. Caglar concluded that these countries should apply related policies to have a permanent impact on emissions. Beşe, Friday, Spencer, and Özden (2021) suggested coal Kuznets curve to be analyzed for developing countries.

\section{MATERIALS AND METHODS}

Time period covers from 1960 to 2019 for India in this study. Variables used in this study are gross domestic production per capita $(\mathrm{G})$ and square of $\mathrm{G}(\mathrm{G} 2)$, and cubic of $\mathrm{G}(\mathrm{G} 3)$, and emissions from coal consumption per capita (coalc). Data for coalc are taken from ourworldindata.org and data for G, G2 and G3 are taken from World Bank database. G values are in form of constant 2010 US\$, and coalc are in form of per capita emissions. The EKC hypothesis is taken as basis in this study. Cubic form of G is taken into consideration for analyzing the relationship between coalc and $\mathrm{G}$ as shown in the model 1 below. Total emissions from coal consumption are not analyzed in this study since the model did not meet stability requirements. Original EKC hypothesis is taken basis and per capita emissions value is used.

$\ln (\text { coalc })_{t}=r_{0}+r_{1} \ln (G)_{t}+r_{2} \ln (G 2)_{t}+r_{3} \ln (G 3)_{t}+e_{t}$

Akaike information criteria is used for lag selection (see Table 1). Zivot and Andrews (1992) unit root test with structural break is used to determine the level of stability for each variable (see Table 2).

ARDL model by Pesaran, Shin, and Smith (2001) is used to investigate the cointegration between the variables. Causal relationships are not investigated since the relationship between the variables is significant only in the short run. Short run and long run coefficients of the variables are examined with ARLD error correction model. ARDL model is used since it is the common methodology used in the literature. Usage of ARDL model also makes this study compatible with the literature.

For determining the stability of the model, Ramsey Reset Test, Heteroskedasticity Test: BreuschPagan-Godfrey, Heteroskedasticity Test: ARCH, Heteroskedasticity Test: White, Breusch-Godfrey Serial 
Correlation LM Test and Normality Test are used to check probability value is higher than $5 \%$. Also Cusum test and Cusum of Squares test are also applied to check blue line is between red lines. Durbin Watson of the model is checked to make sure it is between 1.8 and 2.3. Eviews software is used for all the calculations in this study.

TABLE 1

LAG ORDER SELECTION

\begin{tabular}{|c|c|c|c|c|c|c|}
\hline Lag & LogL & LR & FPE & AIC & SC & HQ \\
\hline 0 & -143.1264 & NA & 0.002250 & 5.254514 & 5.399182 & 5.310602 \\
\hline 1 & 227.7986 & $675.6134^{*}$ & $7.04 \mathrm{e}-09^{*}$ & $-7.421379^{*}$ & $-6.698039^{*}$ & $-7.140942^{*}$ \\
\hline 2 & 232.9215 & 8.599153 & $1.05 \mathrm{e}-08$ & -7.032911 & -5.730900 & -6.528124 \\
\hline 3 & 249.0206 & 24.72354 & $1.07 \mathrm{e}-08$ & -7.036449 & -5.155765 & -6.307312 \\
\hline 4 & 256.1194 & 9.887598 & $1.54 \mathrm{e}-08$ & -6.718548 & -4.259193 & -5.765061 \\
\hline
\end{tabular}

* indicates lag order selected by the criterion

LR: sequential modified LR test statistic (each test at 5\% level)

FPE: Final prediction error

AIC: Akaike information criterion

SC: Schwarz information criterion

HQ: Hannan-Quinn information criterion

TABLE 2

\section{ZIVOT-ANDREW STRUCTURAL BREAK TEST RESULTS}

\begin{tabular}{|c|c|c|c|}
\hline Variables & Level & First Difference & Decision with a structural break \\
\hline COALC & $-2.452981(0)$ & $-4.948403(1)^{* *}$ & $1992-$ Unit root at first difference \\
\hline G & $-3.027293(0)$ & $-7.553348(0)^{*}$ & $2003-$ Unit root at first difference \\
\hline G2 & $-3.158405(0)$ & $-7.747208(0)^{*}$ & $2003-$ Unit root at first difference \\
\hline G3 & $-3.025522(0)$ & $-7.987360(0)^{*}$ & $2003-$ Unit root at first difference \\
\hline
\end{tabular}

*Values are $t$ statistics and the values in the parenthesis are number of lags. * and ** show $1 \%$ and $5 \%$ significancy, respectively.

*Structural break with intercept is calculated for all the variables.

\section{RESULTS}

Bounds test of ARDL model shows that cointegration exists between emissions and economic growth since $\mathrm{F}$ statistic is significant at 5\% (see Table 3). After running error correction model, short run and long run coefficients of the model are calculated (see Table 4, Figure 3, Figure 4, and Figure 5). Model satisfies the stability conditions (see Table 5). Durbin Watson value is 2.19. Break date which is 1992 has insignificant effect on emissions. Although short run results show that economic growth has significant effect on emissions, in the long run this effect becomes insignificant. The trend is first decrease in emissions with economic growth, then increase and then again decrease. Even though coefficients are not significant at $5 \%$, the potential shows economic cycles in the economic system which may be explained by unsustainable economic policies. This study's aim is to analyze the relationship between coal consumption per capita emissions and economic growth in India. The results show that there is insignificant relationship between GDP per capita and emissions from coal consumption per capita. 
TABLE 3

ARDL BOUNDS TEST RESULTS

\begin{tabular}{|c|c|c|}
\hline Test Statistic & Value & $\mathrm{k}$ \\
\hline F-statistic & 4.776227 & 3 \\
\hline \multicolumn{3}{|c|}{ Critical Value Bounds } \\
\hline Significance & I0 Bound & I1 Bound \\
\hline $10 \%$ & 2.72 & 3.77 \\
\hline $5 \%$ & 3.23 & 4.35 \\
\hline $2.5 \%$ & 3.69 & 4.89 \\
\hline $1 \%$ & 4.29 & 5.61 \\
\hline
\end{tabular}

TABLE 4

SHORT RUN AND LONG RUN COEFFICIENTS

\begin{tabular}{|c|c|c|c|c|}
\hline \multicolumn{5}{|c|}{ Short run Coefficients } \\
\hline Variable & Coefficient & Std. Error & t-Statistic & Prob. \\
\hline $\mathrm{D}(\mathrm{G})$ & -1.998040 & 0.813504 & -2.456090 & 0.0174 \\
\hline $\mathrm{D}(\mathrm{G} 2)$ & 0.350687 & 0.138291 & 2.535865 & 0.0143 \\
\hline $\mathrm{D}(\mathrm{G} 3)$ & -0.020066 & 0.007740 & -2.592571 & 0.0123 \\
\hline $\mathrm{D}(\mathrm{D} 1992)$ & 0.015616 & 0.026458 & 0.590200 & 0.5576 \\
\hline CointEq(-1) & -0.159231 & 0.066476 & -2.395317 & 0.0202 \\
\hline \multicolumn{5}{|c|}{ Long run Coefficients } \\
\hline Variable & Coefficient & Std. Error & t-Statistic & Prob. \\
\hline G & -12.548048 & 7.798893 & -1.608952 & 0.1137 \\
\hline G2 & 2.202374 & 1.343354 & 1.639460 & 0.1072 \\
\hline G3 & -0.120912 & 0.075255 & -1.606703 & 0.1142 \\
\hline D1992 & 0.098069 & 0.134238 & 0.730562 & 0.4683 \\
\hline C & 21.487397 & 14.830221 & 1.448893 & 0.1534 \\
\hline
\end{tabular}


FIGURE 3

ARDL MODEL SELECTION

Akaike Information Criteria

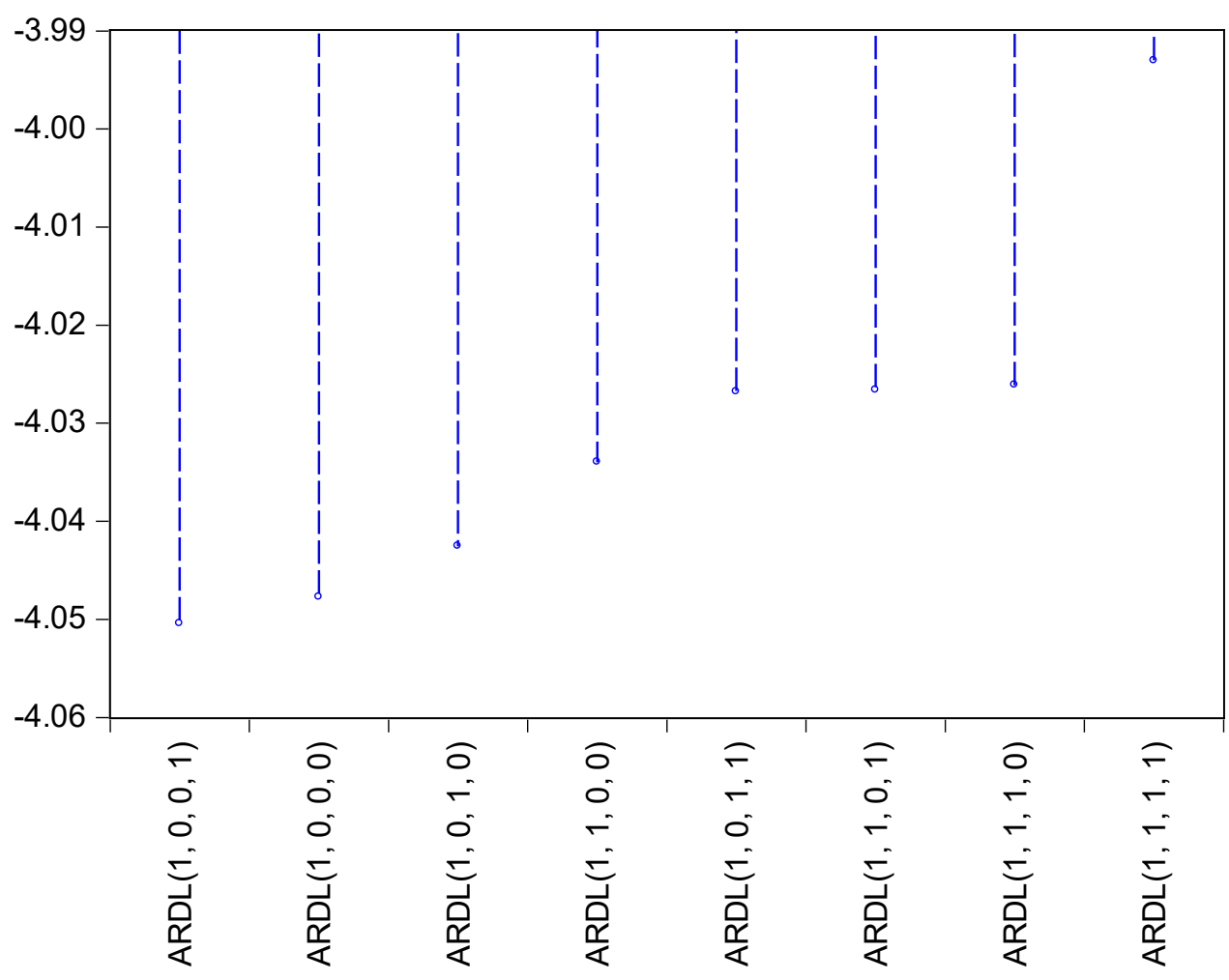

TABLE 5

STABILITY TEST RESULTS

\begin{tabular}{|c|c|c|c|}
\hline Test & F-statistic & Probability & Jarque-Bera \\
\hline Ramsey Reset Test & 0.340217 & 0.5623 & - \\
\hline $\begin{array}{c}\text { Heteroskedasticity } \\
\text { Test: Breusch-Pagan- } \\
\text { Godfrey }\end{array}$ & 1.170881 & 0.3362 & - \\
\hline $\begin{array}{c}\text { Heteroskedasticity } \\
\text { Test: ARCH }\end{array}$ & 0.164121 & 0.6869 & - \\
\hline $\begin{array}{c}\text { Heteroskedasticity } \\
\text { Test: White }\end{array}$ & 0.933113 & 0.5562 & - \\
\hline $\begin{array}{c}\text { Breusch-Godfrey Serial } \\
\text { Correlation LM Test }\end{array}$ & 0.742606 & 0.3929 & 2.269780 \\
\hline Normality Test & - & 0.321457 & \\
\hline
\end{tabular}




\section{FIGURE 4}

\section{CUSUM TEST}

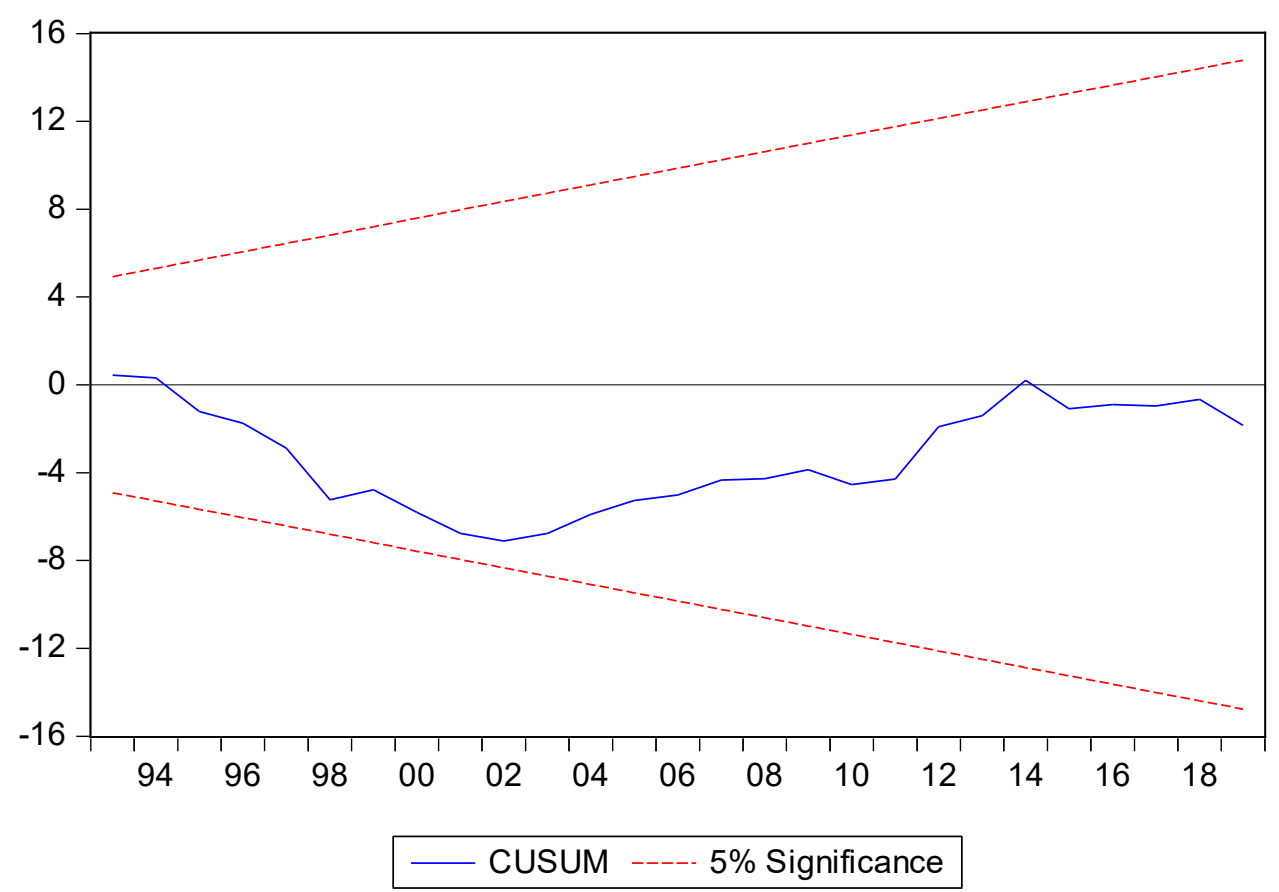

FIGURE 5 CUSUMS TEST

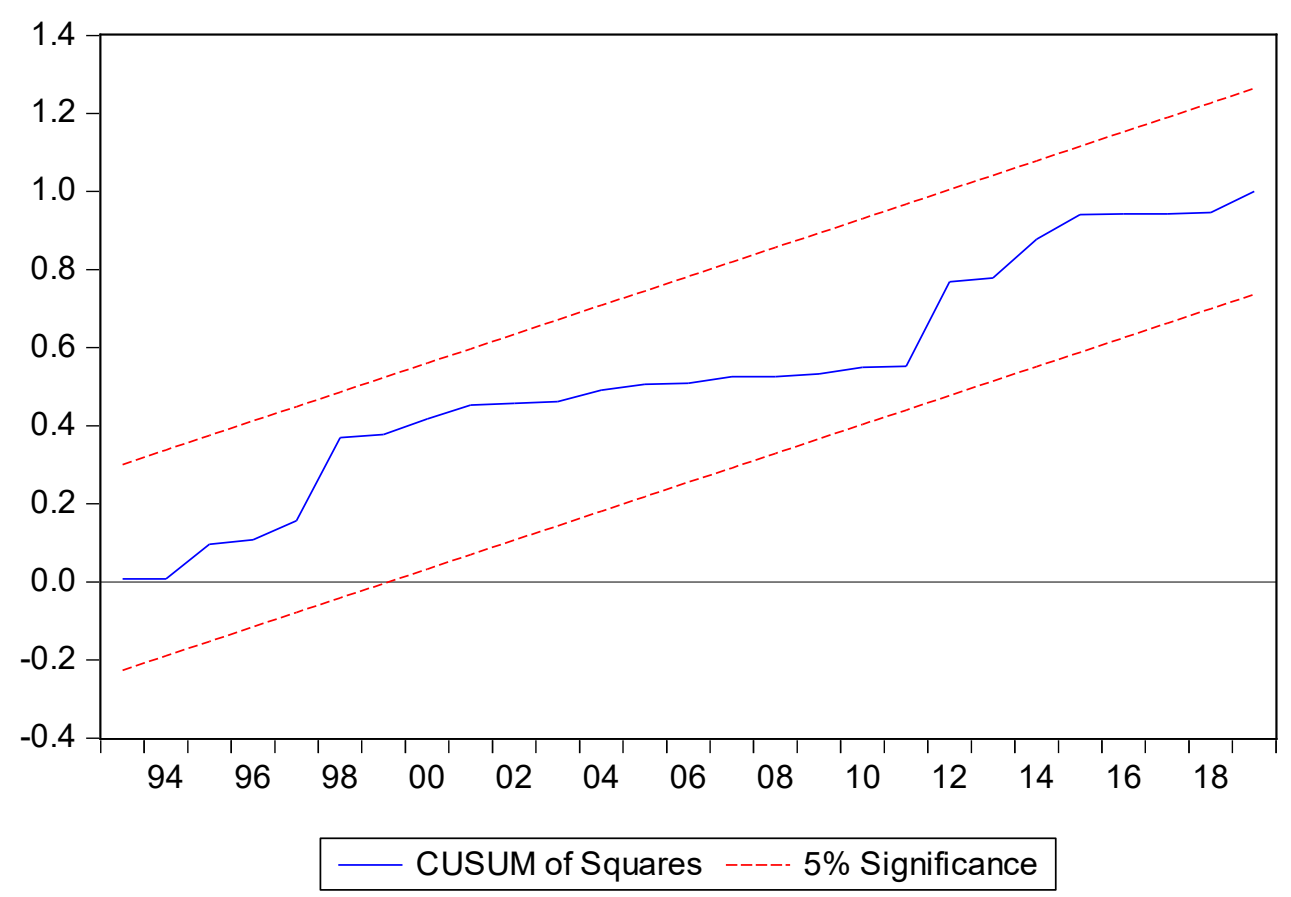

48 Journal of Applied Business and Economics Vol. 23(6) 2021 


\section{DISCUSSION}

For the last ten years, Indian government heavily subsidized, invested and attracted investments for renewable energy industry. Indian government mainly targeted solar and wind power to increase renewable energy levels in India. Indian government also did deep structural reforms for renewable energy industry and needs to do further reforms to support further growth in renewable energy creation also to make it sustainable.

India's current capacity for renewable energy is around 90 gigawatts. India announced that further 50 gigawatts of renewable energy creation capacity is in progress for being installed and Indian government also works for installing around 28 gigawatts of renewable energy creation. Indian government announced that it plans to increase renewable energy creation capacity of the country to around 450 gigawatts by 2030 . After 2030, Indian government aims to fulfill the half of the country's energy demand from renewable energy resources. Also, India decreased its emission intensity significantly. Currently, India is ranked $4^{\text {th }}$ in the world for the renewable energy creation capacity.

India's renewable energy efforts occur mostly because of air pollution and water scarcity. Further public concerns about environmental issues, make the renewable energy investments issues among top issues in India. Those enabled politicians take further steps for increasing renewable energy capacity in India. By taking into consideration air pollution and water security issues, Indian government invested mainly in solar energy besides wind energy creation. Solar energy creation is the one most helps with air pollution and water scarcity. Indian government also has policies for taxing energy sources to protect water resources in the country.

India applies policies to move away from coal and other polluting energy resources by taking support from its people who desire to have a better-quality life with better environmental conditions. India heavily invests in energy storage technologies to be able to eliminate gas and coal industry dependency in the near future. Indian government recently announced that it plans to replace 29 coal plants with renewable energy resources in the near future. It is estimated that coal's share in total energy needs will drop from $70 \%$ to $50 \%$ after 2030. Coal will continue to play a big role in Indian energy market, but sustainable energy policies may make this share smaller each year passing by finally removing India's energy dependency on fossil fuels. Cost reductions for solar and wind energy resources and increase in public concerns for health and environmental issues seem to speed up the transformation of India energy industry to renewable energy resources. This will also help to speed up the closure of old coal plants and not to open new ones in India. Energy security will also play a role in transformation of energy industry because India's energy demand expected to double after 2030 and India wants to fulfill this energy demand with domestic resources.

To enable this energy transformation, Indian government should apply sustainable policies because the result of this study shows that there are unsustainable economic activities in the Indian economy.

\section{CONCLUSION}

The main results of this study are as follows.

- In the short run, there is significant relationship between emissions and economic growth in India.

- In the long run, there is insignificant relationship between emissions and economic growth in India.

- Although the coefficients of economic growth are insignificant, the inverted $\mathrm{N}$ relationship between economic growth and emissions, show that there may be unsustainable energy policy applications in India.

The aim of this study is to analyze the relationship between emissions from coal consumption per capita and economic growth for India for the period 1960 to 2019. The results show that there is significant relationship in the short run and insignificant relationship in the long run. Further causality relationship is not explored since the significant relationship exists in the short run. Although insignificant, inverted $\mathrm{N}$ 
relationship exists between emissions and economic growth in India. This may relate to unsustainable economic policies in India that relates to energy sector.

For policy recommendations, Indian government should pursue sustainable policies for supporting renewable energy sector and transforming overall energy sector in India. Indian government should also continue to invest in energy storage technologies by establishing international cooperation to eliminate its dependency on oil and gas energy resources. Indian government should continue to subsidize renewable energy industry and support foreign direct investment towards renewable energy capacity creation.

The limits of this study are that country of the study is India and the period analyzed is from 1960 to 2019.

This study recommends that future studies may analyze different periods with different methodologies to study the relationship between coal consumption and economic growth in India by also analyzing total emissions from coal consumption to further contribute to the literature.

\section{REFERENCES}

Abul, S.J., Satrovic, E., \& Muslija, A. (2019). The Link Between Energy Consumption and Economic Growth in Gulf Cooperation Council Countries. International Journal of Energy Economics and Policy, 9(5), 38-45. https://doi.org/10.32479/ijeep.7872

Ahmad, M., Muslija, A., \& Satrovic, E. (2021). Does economic prosperity lead to environmental sustainability in developing economies? Environmental Kuznets curve theory. Environmental Science and Pollution Research, 28(18), 22588-22601. https://doi.org/10.1007/s11356-02012276-9

Alam, R., \& Adil, M.H. (2019). Validating the environmental Kuznets curve in India: ARDL bounds testing framework. OPEC Energy Review, 43(3), 277-300. https://doi.org/10.1111/opec.12156

Azam, M. (2019). Relationship between energy, investment, human capital, environment, and economic growth in four BRICS countries. Environmental Science and Pollution Research, 26, 3438834400 .

Balli, E., Nugent, J.B., Coskun, N., \& Sigeze, C. (2020). The relationship between energy consumption, $\mathrm{CO} 2$ emissions, and economic growth in Turkey: Evidence from Fourier approximation. Environmental Science and Pollution Research, 27, 44148-44164.

Bese, E., \& Friday, H.S. (2021). The Effect of the Kyoto Protocol. Australian Journal of Business and Management Research, pp. 1-31.

Beşe, E., Friday, H.S., \& Ozden, C. (2021). The Effect of External Debt on Emissions: Evidence from China. International Journal of Energy Economics and Policy, 11(1), 440-447.

Beşe, E., Friday, H.S., \& Özden, C. (2020). Coal Consumption Environmental Kuznets Curve (EKC) in China and Australia: Evidence From ARDL Model. Journal of Applied Business and Economics, 22(11), 25-36.

Beşe, E., Friday, H.S., \& Spencer, M. (2021). Analysis of the Relationship Between Income Growth and, Coal Consumption and Emissions from Nonlinear Perspective. Journal of Academy of Business and Economics, 21(1), 52-72. Retrieved from http://158.132.160.122/handle/10397/15264

Beşe, E., Friday, H.S., Spencer, M., \& Özden, C. (2021). Analysis of the Literature for Carbon Kuznets Curve. Journal of Strategic Innovation and Sustainability, 16(1).

Beşe, E., \& Kalayci, S. (2019a). Environmental Kuznets Curve (EKC): Empirical Relationship Between Economic Growth, Energy Consumption, and CO2 Emissions: Evidence from 3 Developed Countries. Panoeconomicus, pp. 1-26.

Beşe, E., \& Kalayci, S. (2019b). Testing the Environmental Kuznets Curve Hypothesis: Evidence from Egypt, Kenya and Turkey. International Journal of Energy Economics and Policy, 9(6), 479-491.

Caglar, A.E. (2020). The importance of renewable energy consumption and FDI in flows in reducing environmental degradation: Bootstrap ARDL bound test in selected 9 countries. Journal of Cleaner Production, 264, 121663. https://doi.org/10.1016/j.jclepro.2020.121663 
Chisti, K.A., \& Shabir, T. (2019). Impact of External Debt on Various Macro Economic Variables: Indian Evidence. Journal of Economics, Management and Trade, 25(4), 1-16. https://doi.org/10.9734/jemt/2019/v25i430199

Hao, Y., Liu, Y., Weng, J.H., \& Gao, Y. (2016). Does the Environmental Kuznets Curve for coal consumption in China exist? New evidence from spatial econometric analysis. Energy, 114, 1214-1223. https://doi.org/10.1016/j.energy.2016.08.075

Irfan, M., Rao, M.W., Akbar, J., \& Younis, I. (2020). Impact of External Debt on Stock Market Performance and Economic Growth: Moderating Role of Capital Formation. Journal of Finance and Accounting Research, 2(1), 1-28.

Joy, J., \& Panda, P.K. (2019). Pattern of External Debt and its Impact on Macroeconomic Variables in India. International Journal of Economic Research, 16(1), 261-272.

Khan, A., Chenggang, Y., Yi, W.X., Hussain, J., Sicen, L., \& Bano, S. (2020). Examining the pollution haven, and environmental kuznets hypothesis for ecological footprints: An econometric analysis of China, India, and Pakistan. Journal of the Asia Pacific Economy, pp. 1-21. https://doi.org/10.1080/13547860.2020.1761739

Magazzino, C., Bekun, F.V., Etokakpan, M.U., \& Uzuner, G. (2020). Modeling the dynamic Nexus among coal consumption, pollutant emissions and real income: Empirical evidence from South Africa. Environmental Science and Pollution Research, 27(8), 8772-8782. https://doi.org/10.1007/s11356-019-07345-7

Murthy, K.V.B., \& Gambhir, S. (2018). Analyzing Environmental Kuznets Curve and Pollution Haven Hypothesis in India in the Context of Domestic and Global Policy Change. Australasian Accounting, Business and Finance Journal, 12(2), 134-156. https://doi.org/10.14453/aabfj.v12i2.9

Muslija, A., Satrovic, E., \& Erbaş, C.Ü. (2017). Panel Analysis of Tourism - Economic Growth Nexus. International Journal of Economic Studies, 3(4), 535-545.

Nath, S. (2020). An Analysis of the Relationship among Economic Growth, External Debt and Exports in India (1970-2018). Economy, 7(1), 59-68. https://doi.org/10.20448/journal.502.2020.71.59.68

Özden, C., \& Beşe, E. (2021). Environmental Kuznets Curve (EKC) in Australia: Evidence from Nonlinear ARDL Model with a Structural Break. Polish Journal of Environmental Studies, 30(3), 1-11. https://doi.org/10.15244/pjoes/127555

Pahwa, N. (2018). Impact of debt on short-run and long-run growth: Empirical evidence from india. In Current Issues in Economics and Finance (pp. 3-18). https://doi.org/10.1007/978-981-10-581031

Pesaran, M.H., Shin, Y., \& Smith, R.J. (2001). Bounds testing approaches to the analysis of level relationships. Journal of Applied Econometrics, 16(3), 289-326. https://doi.org/10.1002/jae.616

Satrovic, E., \& Muslija, A. (2018, September). Economic and Demographic Determinants of the Demand for Life Insurance: Multivariate Analysis. Yönetim ve Ekonomi Araştırmaları Dergisi, 16, 102115. https://doi.org/10.11611/yead.442827

Satrovic, E., Muslija, A., \& Abul, S.J. (2020). The Relationship between CO2 Emissions and Gross Capital Formation in Turkey and Kuwait. South East European Journal of Economics and Business, 15(2), 28-42. https://doi.org/10.2478/jeb-2020-0013

Saxena, S.P., \& Shanker, I. (2017). External debt and economic growth in India. Social Science Asia, 4(1), 15-25. Retrieved from http://www.doiserbia.nb.rs/Article.aspx?ID=1452-595X1406669A

Sinha, A., \& Bhatt, M. (2017). Environmental Kuznets Curve for Co2 and Nox Emissions: A Case Study of India. European Journal of Sustainable Development, 6(1), 267-276. https://doi.org/10.14207/ejsd.2017.v6n1p267

Sultan, Z.A., Alkhateeb, T.T.Y., \& Adow, A.H. (2021). Verifying the Environmental Kuznets Curve Hypothesis in the Case of India. International Journal of Energy Economics and Policy, 11(2), $127-132$. 
Tirgil, A., Acar, Y., \& Ozgur, O. (2021). Revisiting the environmental Kuznets curve: Evidence. Environment, Development and Sustainability, (0123456789). https://doi.org/10.1007/s10668021-01259-6

Verbic, M., Satrovic, E., \& Muslija, A. (2021). Environmental Kuznets curve in Southeastern Europe: The role of urbanization and energy consumption. Environmental Science and Pollution Research. https://doi.org/10.1016/j.rser.2012.10.012

Zivot, E., \& Andrews, D.W.K. (1992). Further Evidence on the Great Crash, the Oil-Price Shock, and the Unit-Root Hypothesis. Journal of Business \& Economic Statistics, 10(3), 25-44. 